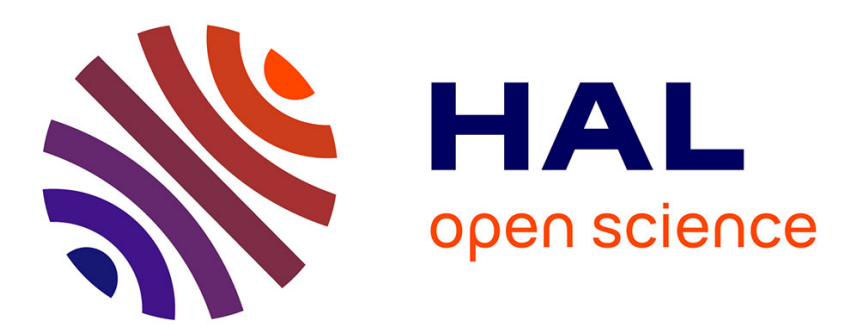

\title{
Reservoir properties of Turonian rudist-rich carbonates in Central Tunisia (the onshore of Sfax area)
}

Senda Boughalmi, Mohamed Hédi Negra, Danièle Grosheny, Yves Géraud, Moncef Saidi

\section{- To cite this version:}

Senda Boughalmi, Mohamed Hédi Negra, Danièle Grosheny, Yves Géraud, Moncef Saidi. Reservoir properties of Turonian rudist-rich carbonates in Central Tunisia (the onshore of Sfax area). Arabian Journal of Geosciences, 2019, 12 (15), 10.1007/s12517-019-4632-5 . hal-02457286

\section{HAL Id: hal-02457286 \\ https://hal.univ-lorraine.fr/hal-02457286}

Submitted on 6 Oct 2020

HAL is a multi-disciplinary open access archive for the deposit and dissemination of scientific research documents, whether they are published or not. The documents may come from teaching and research institutions in France or abroad, or from public or private research centers.
L'archive ouverte pluridisciplinaire HAL, est destinée au dépôt et à la diffusion de documents scientifiques de niveau recherche, publiés ou non, émanant des établissements d'enseignement et de recherche français ou étrangers, des laboratoires publics ou privés. 


\title{
Reservoir properties of Turonian rudist-rich carbonates in Central Tunisia (the onshore of Sfax area)
}

\author{
Senda Boughalmi ${ }^{1}$ \& Mohamed Hédi Negra ${ }^{1}$ \& Danièle Grosheny ${ }^{2}$ \& Yves Géraud ${ }^{2}$ \& Moncef Saidi ${ }^{3}$
}

\begin{abstract}
The present study is based on core petrographical analyses of an oil-producing Turonian carbonate reservoir in the Sfax area (central-eastern onshore of Tunisia). Sedimentological studies show that these Early-Middle Turonian carbonates consist of shallow marine bioclastic limestones, sometimes partly dolomitised, and are rich in rudists which can be associated to other bivalves, gastropods, oncoliths, benthic foraminifers and calcisphers. Facies are organised into metre-scale shallowing upward cycles, each comprising three units corresponding, from base to top, to the following: bedded, slightly argillaceous wackestones containing floating rudist debris and sometimes calcisphers; alternation of massively bedded partly dolomitised packstones rich in entire joined rudists and finely bedded wackestones-packstones containing miliolids, oncoliths and gastropods; and micritic carbonates, partly argillaceous, nodular shaped and laminated. In terms of reservoir properties, the highest values of helium porosity (reaching 27\%) and permeability (reaching $700 \mathrm{mD}$ ) were measured in rudist-rich carbonates. Pores, which are partly filled with oil, mainly correspond to the Radiolitid cells. In addition, some diagenetic features such as dolomitisation, dedolomitisation and dissolution have created additional pores and have clearly enhanced the reservoir potential of these rudist-rich carbonates.
\end{abstract}

Keywords Upper Cretaceous . Turonian . Bireno . Reservoir . Sedimentology . Petrophysics

\section{Introduction}

The Late Cretaceous carbonate series are well represented on the southern margin of the Tethys (Masse and Philip 1981; Philip 1985; Skelton and Gili 1991; Abdallah et al. 2000; Scott 2003; Skelton 2003; Philip 2003; Grosheny et al. 2013; Lebedel et al. 2015; Jaballah 2017). In central and southern Tunisia, these series, generally rich in rudists

(M’Rabet et al. 1986; Zagrarni 1999; Troudi et al. 2002; Zagrarni et al. 2003; Touir et al. 2009; Negra et al. 2016), are characterised by variations in thickness and facies (Salmouna-Jomaa et al. 2014; Salmouna-Jomaa 2017). These variations which clearly appear along transects, mainly oriented north-south and northeast-southwest (Jaballah and Negra 2016; Jaballah 2017), could be controlled by local (tectonic) and global (eustatic) factors.

From the petroleum system point of view, the Late Cretaceous carbonate facies in Tunisia, especially those of the Cenomanian-Turonian (Gattar and Bireno Members) and those of the Coniacian (Douleb Member) belonging to the Turonian-Early Campanian Aleg Formation (Fig. 1), are known for their good reservoir quality. In fact, they are productive in several sectors of Tunisia, notably in Sfax area (such as Geubiba, El Ain and Rhemoura oil fields (M'Rabet et al. 1995; Chaabouni 1996; Saïdi et al. 1997; Troudi et al. 1999; Troudi et al. 2002) and the Gulf of Gabes (such as Miskar field) (M'Rabet et al. 1995; Lansari et al. 2006, 2010).

In Tunisia, Early-Middle Turonian carbonates (Bireno Member, Fig. 1) are mainly deposited in central Tunisia and in the south-eastern part of Tunisia, along a roughly W-E

trending belt extending from Kasserine to the northern part of the Gulf of Gabes. This rudist belt is a part of a platform occupying the central south-eastern Tunisia. However, from the south-west part to the north-east part of this platform, facies exhibit lateral changes in facies, depositional environments, diagenetic features and reservoir properties.

Based on sedimentological analyses and petrophysical measurements, the objective of this paper is to determine the characteristics of oil-bearing carbonate core samples taken from the Early-Middle Turonian rudist reservoir (Bireno Member, Fig. 1), located in central Tunisia (Fig. 2). It is also to explain why the impregnation (oil shows) only concern some types of carbonates and to mention which facies have the best petrophysical characteristic for oil exploitation. 


\section{Geological setting}

The studied carbonate reservoir corresponds to the Turonian rudist interval of a well located in Late Cretaceous, Paleogene and Neogene series. This well is located in the onshore of Sfax area (Fig. 2), east-central part of Tunisia. It lies on the Pelagian Platform, where in the Early Cretaceous to Eocene, an incipient rift system developed. This rift system is expressed as a series of horsts and tilted blocks (Zouari et al. 1999), and it corresponds to a portion of the Atlasic domain collapsed at the Plio-Quaternary (Martinez and Truillet 1987).

The located study (Fig. 3) is a subsident domain of the Pelagian Platform and marks the sinking of the Saharan Platform towards the Central Mediterranean (Ben Ayed 1986). In this oriental area, under a thick Neogene series slightly undulating in NW-SE directions (Ben Ayed 1986; Martinez and Truillet 1987; Touati and Rodgers 1998).

The Cenomanian-Turonian Bahloul Formation, covering the east-central part of Tunisia, is considered as a main source rock for the Cretaceous reservoirs, notably the Douleb one (Troudi et al. 2002).

According to Troudi et al. (2002), the Bahloul Formation is proven to be the source of several crude oils produced in the Pelagian Platform. Stable carbon isotope and biomarker data indicate that the Bahloul Formation is the predominant source rock for oil within the Bireno reservoir. It is a good potential source rock as indicated by TOC values (up to $14 \%$ ) and a genetic potential (up to $70 \mathrm{~kg}$ ) of hydrocarbon/ton of rock.

\section{Material and methods}

The present work is based on sedimentological and petrophysical analyses. For sedimentological studies, macroscopic analysis was undertaken in order to recognise the main sedimentological features of ten cores along $106 \mathrm{~m}$ of series. The following microscopic analyses ofthin sections were conducted using polarising microscopy to highlight the texture, structure, bioclasts contents, porosity type and the diagenetic processes. The more detailed analyses using the scanning electron microscopy (SEM) have only concern micritic samples.

For petrophysical study, measurements of density, helium porosity and nitrogen permeability were carried out on samples having $2.54 \mathrm{~cm}$ (1 in.) in diameter and between 3.4 and $4.1 \mathrm{~cm}$ in length.

The porosity $(\varphi)$ is defined as the ratio of the void volume to the total volume of the material (Zinszner and Pellerin 2007). In the rock, porosity could be composed by connected or isolated pores with various shapes (Norton and Knapp 1977). The UltraPore $^{\mathrm{TM}} 300$ helium porosimeter uses Boyle's law to determine the grain volume from the expansion of a known mass of helium into a calibrated sample holder. Helium, being a rare and light gas, has the property of being easy to penetrate and saturate the pores of the sample. Boyle's law is expressed as follows:

$\mathrm{P}_{1} \mathrm{~V}_{1} \mathrm{P}_{2} \mathrm{~V}_{2}$

$\longrightarrow-\mathrm{T}_{1} 1 / 4 \mathrm{~T}_{2}$

ð

where $P_{1}$ is the initial pressure, $V_{1}$ is the initial volume, $T_{1}$ is the initial absolute temperature, $P_{2}$ is the expanded pressure, $V_{2}$ is the expanded volume, and $\mathrm{T}_{2}$ is the expanded absolute temperature.

The equation used to calculate grain volume is derived from the basic Boyle's law equation which is expressed as follows:

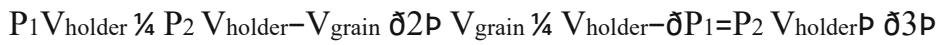

where $\mathrm{V}_{\text {holder }}$ is the holder's volume and $\mathrm{V}_{\text {grain }}$ is the volume of solid phase.

Knowing the mass of the sample under dry condition, the grain density $\left(\mathrm{d}_{\mathrm{sp}}, \mathrm{g} / \mathrm{cm}^{3}\right)$ is calculated as follows:

$\mathrm{dsp}^{1 / 4} \frac{\mathrm{W}_{\mathrm{d}}}{\mathrm{V}_{\text {grain }}}$

ðP 
The porosity is inferred using the solid-phase density obtained from the helium pycnometer test and the bulk density obtained from triple weight measurements. The porosity was calculated by using the following equation:

$\varphi \frac{1 / 41-\mathrm{d}_{\mathrm{b}}}{{ }^{2}} 100$ ð5p dsp

Permeability (K) refers to the ability of a material to transmit fluids, and therefore, it is closely related to the intrinsic properties of the porous material (mainly the size, the shape and the connectivity of the porous network), to the viscosity of the fluid and to the external conditions such as the fluid pressure gradient (Scheidegger 1974; Homand and Duffaut 2000). The gas permeameter UltraPerm ${ }^{\mathrm{TM}} 400$ uses Darcy's law to calculate the permeability from the gas flow rate and the measured upstream and downstream pressures

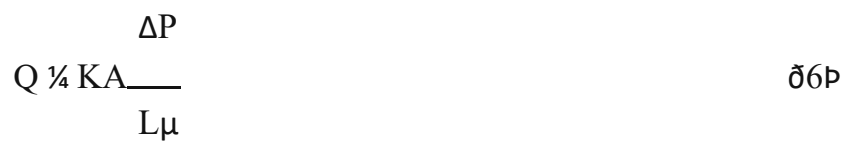

where $\mathrm{Q}$ is the volumetric flow $\left(\mathrm{m}^{3} / \mathrm{s}\right), \mathrm{K}$ is the permeability coefficient $(\mathrm{mD}), \mathrm{A}$ is the area of the section studied $\left(\mathrm{cm}^{2}\right), \Delta \mathrm{P}$ is the pressure gradient between the top and the bottom of the sample (atm), $\mathrm{L}$ is the length of the sample (cm) and $\mu$ is the viscosity of fluid (cP).

\section{Results and discussion}

\section{Sedimentological properties of the Turonian Bireno Member}

Lithostratigraphy of the Bireno Carbonates Member

In the studied well, the thickness of the Bireno Member is $106 \mathrm{~m}$. According to the lithology and the fossiliferous content, three distinct lithological units are identified (Fig. 4):

\&Unit 1 (U1): a clayey-carbonate unit with a thickness of 18

$\mathrm{m}$. This unit is subdivided into two sub-units:

- The basal sub-unit (U1 a) is composed ofgreyargillaceous limestones, strongly fractured, showing a wackestonepackstone texture containing rudist-debris such as Hippuritidae and Radiolitidae (Negra and Philip 1987), calcisphers and some dolomitised bioclasts.

- The upper sub-unit ( $\mathrm{U}_{\mathrm{b}}$ ) is formed of beige-brown dolomicrites, showing birdseyes and parallel lamination (Fig. 5a).

\& Unit 2 (U2): an oil-impregnated carbonate unit with a thickness of $56 \mathrm{~m}$ and marked by the presence of many fractures (open or cemented). This unit is composed of the superimposition of two sub-units (U2a and $U 2 b$ ) showing shallowingup sequences starting with rudist-rich limestones and ending with micritic limestones containing miliolids and oncoliths (Fig. 4):

The first sub-unit (U2a: U2a1, U2a2, U2a3), formed of brown dolomitised limestones (Fig. 5b) showing a wackestonepackstone texture. It contains large debris of entire and joined rudists of Hippuritidae (Fig. 6b) and Radiolitidae type (Fig. 6a, c). These rudist layers are marked by the presence of some quartz grains observed in the matrix or within the rudists. 
- The second sub-unit (U2b: $\mathrm{U} 2 \mathrm{~b}_{1}$ and $\mathrm{U} 2 \mathrm{~b}_{2}$ ), formed of micritic limestones showing a wackestone-packstone texture, containing miliolids (Fig. 6e, f), oncoliths (Fig. 5c) and scarce ooliths, gastropods (Fig. 6f), peloids, echinoderms and algae debris at the submittal part of the sequence.

\& Unit 3 (U3): This unit (32 m thick) is composed of micritic carbonates, partlyargillaceous, nodular tolaminated,bearing two laminated oil-impregnated dolomitic layers (Fig. 5d). A microscopic study of thin sections shows that the dolomite beds were former miliolid-bearing packstonesmudstones. This unit is also marked by the abundance of stylolites and microfractures partly cemented by calcite or pyrite.

Comparative to the Jebel Bireno section (Zagrarni et al. 2008), outcropping at Kasserine area, the Bireno Member includes frequent high-energy deposits in sequences starting withbioclastic limestonesrichinsortedrudistdebris and some geniculate forms of Hippuritids (Skelton and Gili 1991), and ending with entire rudist-rich lithosomes (Negra and Zagrarni 2007; Zagrarni et al. 2008), the south-eastern part of the Turonian carbonate platform appears relatively more restricted.

\section{Depositional environment of Bireno Carbonates Member}

The Bireno Member reveals diverse facies associations, evolving from supratidal to fore shoal environments (Fig. 7). These facies characterise a ramp-type platform (Saïdi et al. 1997; Zagrarni 1999; Zagrarni et al. 2007; Salmouna-Jomaa 2017).

The tidal flat zone is represented by laminated dolomites showing birdseye fabric occurring in the first unit (U1b) and by dolomites with laminated and wavy structures within the third unit (U3). The innermost platform facies is interpreted as passing seaward to a lagoonal environment represented by micritic limestones rich in miliolids, oncoliths, gastropods and peloids belonging to $\mathrm{U} 2$ and dolomicritic facies (U3).

Limestones rich in entire joined rudists (Hippuritidae and Radiolitidae) and oysters are ascribed to a shoal environment (Rudistic shoal) rimming the lagoon. Finally, the mid-outer ramp transitional faciesconsist ofargillaceouslimestonescontaining rudist-debris and calcisphers $\left(\mathrm{U} 1_{\mathrm{a}}\right)$ characterising the fore shoal deposits.

\section{Petrophysical characteristics of the Bireno Member}

\section{The Bireno Carbonates Member density values}

Most density values (Fig. 8) vary from 2.67 to $2.75 \mathrm{~g} / \mathrm{cm}^{3}$, in accordance with calcite as the main mineral of the different sets of samples.

Samples with density values between 2.75 and $2.85 \mathrm{~g} / \mathrm{cm}^{3}$ correspond to dolomites. Layers with density values lower than $2.69 \mathrm{~g} / \mathrm{cm}^{3}$ contain quartz crystals, while those with higher values $\left(2.96 \mathrm{~g} / \mathrm{cm}^{3}\right)$ contain heavy minerals.

Petrographical analyses confirm the obtained results.

\section{Vertical evolution of porosity and permeability}

Porosity values cover a broad range from 0.1 to $27 \%$, as well as for permeability (from 0.01 to $700 \mathrm{mD}$, Fig.9).Some layers show negligible permeability values $(<0.01 \mathrm{mD}$ : apparatus measurement limit).

Porosity and permeability overall increase and decrease simultaneously (Fig. 9). The relationship between these two petrophysical parameters is shown in the logarithmic graph (Fig. 10). In this graph, the distribution of points indicates the clear influence of the porosity on the permeability and shows that there is a clear correlation between these two petrophysical parameters. Two groups of points are distinguished (Fig. 9) as follows:

\& The first group (G1) is represented by a horizontal straight line where the porosity values increase (from 0 to $11 \%$ ) while the permeability remains constant and negligible $(<0.01 \mathrm{mD})$. It corresponds to the summital part of the Bireno Member (U3). It is a fine-grained unit composed of micritic facies, partly argillaceous. These facies are affected by a strong compaction expressed by the development of numerous stylolithes. In addition to compaction, these facies are affected by silicification processes that are expressed by the neogenesis of automorphic quartz crystals which particularly occur within the matrix. Also, these layers are affected by the cementation of fractures by calcite and the micritisation of 
bioclasts especially miliolids. These diagenetic processes which involve cementation of the pores decrease the porosity and the permeability of these facies.

\& The second group (G2), which is rather grouped, corresponds to an evolution of the permeability parallel to that of the porosity (between 0.1 and $27 \%$ for porosity and between 0.1 and $700 \mathrm{mD}$ for permeability). It shows that porosity and permeability generally increase and decrease correlatively. Therefore, the low permeability intervals coincide with the low porosity intervals. Similarly, the intervals of high permeability generally coincide with those of good porosity.

\section{Relationship between petrophysical properties and microfacies characteristics}

From a petroleum perspective and on the basis of petrophysical analyses, it appears that the highest values of porosity and permeability occur within bioclastic limestones rich in rudists and micritic limestones containing miliolids, oncoliths and some gastropods belonging to U2, impregnated by oil, and exhibit good values. However, in terms of reservoir properties, the highest values of helium porosity (reaching 27\%) and permeability (reaching $700 \mathrm{mD}$ ) were measured in rudist-rich carbonates (Fig. 9). These facies are characterised by a complex porous system that include intragranular (Figs. 6a-d, f and 11d, f), intergranular (Figs. 6c, e and 11h), intercrystal (Fig. 11a, b, e), intracrystal (Fig. 11c) and fracture porosity. The matrix porosity is only identified in micritic limestones with a wackestone-packstone texture containing oncoliths, miliolids and gastropods (Fig. 6e, f).

A microscopic study has shown that these facies are mainly affected by dissolution, matrix dolomitisation (Fig. 11a, b, e) and dedolomitisation (Fig. 11c) that create a significant secondary porosity (intercrystal or moldic and intracrystal). These diagenetic processes improve the porous system.

Vertically, rudist facies show varied values of porosity (Fig. 9). Some layers show the best porosity values (reaching $27 \%$ ). In other layers, the mean porosity is comprised between 10 and $15 \%$. On the basis of petrographical analyses, this difference in values is explained by diagenetic processes affecting these facies. The decrease of porosity is mainly due to silicification of bioclasts, cementation of rudist pores and cavities by calcite (Fig. 6d) or anhydrite (Fig. 11h), recrystallisation of bioclasts (by calcite or dolomite) and intrabioclastic dolomitisation (intra-Radiolitidae, Fig. 11d). In fact, it appears that dolomitisation, for example, is a diagenetic process that could be both ameliorative and destructive at the same time. It can lead to porogenesis by creating secondary porosity or poronecrose by cementing Radiolitid pores (Fig. 11d) or microfractures (Fig. 11g) by rhombohedral dolomite crystals.

In the second unit (U2), it has been shown that some layers have good porosity values. However, these facies do not show traces of hydrocarbons (oil impregnation). This can be explained by the low values of permeability. The micropores are not connected enough in relation with the lack of microfractures or the total cementation of microfractures with sparry calcite.

In terms of the diagenesis phase chronology versus migration and trapping phases, most of diagenetic fabrics enhancing the reservoir properties, such as dolomitisation, dedolomitisation and dissolution, have occurred before fluid migration and trapping genesis.

However, cementation, compaction and silicification processes appear to be the latest phases that occur after oil migration.

\section{Conclusions}

From a petroleum perspective and on the basis of layering based on sedimentological and petrophysical analyses, it appears that Turonian carbonates in the studied well have a petroleum interest and can be considered as a potential regional reservoir layer. Our established layering shows that the facies of the second unit are impregnated with oil and have the best petrophysical values.

The impregnated facies consist of both bioclastic wackestones-packstones rich in rudists and finer wackestonespackstones rich in miliolids, oncoliths and gastropods. The best impregnated layers showing the best petrophysical characteristics (highest porosity and permeability values) correspond to dolomitised packstones rich in rudists (Hippuritids and Radiolitids).

Petrographical and petrophysical analyses show that the evolution of the porosity (increase or decrease) is under the influence of these types of diagenetic modifications. Matrix dolomitisation, dedolomitisation and dissolution are the main 
diagenetic processes that improve the porous system, whereas compaction, silicification, recrystallisation and cementation can completely destroy it. Permeability is significantly enhanced by fracturing.

These facies are characterised by a complex porous system that include matrix, intercrystalline, fracture, intergranular and intragranular porosities.

Acknowledgements This paper is a part of the PhD thesis of the first author at the University of Tunis El Manar. The authors greatly thank the anonymous reviewers for their helpful and constructive comments that improved the manuscript. We express our sincere thanks to Entreprise Tunisienne d'Activités Pétrolières (ETAP) for allowing the publication of these results. 


\section{References}

Abdallah H, Sassi S, Meister C, Souissi R (2000) Stratigraphie intégrée et paléogéographie des séries sédimentaires à la limite CénomanienTuronien dans la région Gafsa-Chotts (Tunisie centrale). Cretac Res 21:35-106. https://doi.org/10.1006/cres.2000.0200

Ben Ayed N (1986) Evolution tectonique de l'avant-pays de la chaîne alpine de Tunisie du début de mésozoïque à l'actuel. Thèse d'état. Université de Paris-Sud, Orsay, France, 286 p

Chaabouni M (1996) The Bireno Member excellent potential reservoir in central Tunisia. Entreprise Tunisienne d'activité Pétrolières (ETAP), EPC 10:331-335

Grosheny D, Ferry S, Jati M, Ouaja M, Bensalah M, Atrops F, ChikhiAouimur F, Benkerouf-Kechid F, Negea MG, Ait Salem H (2013) The Cenomanian-Turonian boundary on the Saharn Platform

(Tunisia and Algeria). Cretac Res 42:1-19. https://doi.org/10.1016/ j.cretres.2013.01.004

Homand F, Duffaut P (2000) Manuel de mécanique des roches. Ecole des Mines, Paris $265 \mathrm{p}$

Jaballah J (2017) Les séries du Crétacé supérieur (Albien-Campanien inférieur) en Tunisie Centrale Méridionale. Caractères sédimentaires et intérêt économique. Thèse. Doc. Université. Tunis, $289 \mathrm{p}$.

Jaballah J, Negra MH (2016) Stratigraphical and sedimentary characters of Late Cretaceous formations outcropping in central and southern Tunisia, Tethyan southern margin. J Afr Earth Sci 124:289-310. https://doi.org/10.1016/j.jafrearsci.2016.09.020

Klet TR (2001) Total petroleum systems of the Pelagian Province, Tunisia, Libya, Italy, and Malta - the Bou Dabbous-Tertiary and JurassicCretaceous composite. U.S. Geological Survey Bulletin 2202-D

Lansari F, Hamouda F, Negra MH (2006) The Upper Cretaceous carbonatic facies in central-east Tunisia: electrofacies, sedimentary characters and economic implications. Proceedings of the 10th Tunisian Petroleum Exploration \& Production Conference. Entreprise Tunisienne d'Activités Pétrolières (ETAP). EPC 98-122.

Lansari F, Troudi H, Negra MH (2010) Outcrops-subsurface lithostratigraphic correlations of the Bireno carbonatic reservoir in Central Tunisia. Proceedings of the 12th Tunisian Petroleum Exploration \& Production Conference. Entreprise Tunisienne d'Activités Pétrolières (ETAP). EPC 63-69

Lebedel V, Lézin C, Andreu B, Ettachfini M, Grosheny D (2015) The upper Cenomanian-lower Turonian of the Preafrican trough (Morocco): platform configuration and paleo-environmental conditions. J Afr Earth Sci 106:1-16. https://doi.org/10.1016/j.jafrearsci. 2015.03.001

M'Rabet A, Negra MH, Purser BH, Sassi S, Ben Ayed N (1986) Micrite diagenesis in Senonian rudist buildups in central Tunisia. In: Purser BH, Schroeder JH (eds) Reef diagenesis. Springer, Berlin, pp 210- 223

M'Rabet A, Mejri F, Burollet PF, Memmi L, Chandoul H (1995) Catalog of types sections in Tunisia: cretaceous. Entreprise Tunisienne d'Activités pétrolières (ETAP). Mem. 8A. Tunisia

Marie J, Trouvé P, Desforges G, Dufour P (1984) Nouveaux éléments de paléogéographie du Crétacé de Tunisie. Cretac Res 3:167-170

Martinez C, Truillet R (1987) Evolution structurale et paléogéographique de la Tunisie. Memoria de la Societa Italiana de Geologia 38:35-45

Masse JP, Philip J (1981) Cretaceous coral-rudistid buildups of France. In: Fossil reef models, European. In: Toomey DF (eds) Soc Econ Paleont Mineral, special 30:399-426

Negra MH, Philip J (1987) Stratigraphie etpaléontologiedes formationsà rudistes et grands foraminifères du Campanien du Jebel Kébar (Tunisie Centrale). Géol Méditerr 12/13(for 1985/6):49-57

Negra MH, Zagrarni MH (2007) Upper Cretaceous tempestites in rudistrich facies, Tunisia. SEPM (Society for Sedimentary Geology), Special Publication No. 87, ISBN 978-1-56576-127-8, pp. 45-56. https://doi.org/10.2110/pec.07.87.0045

Negra MH, Skelton P, Gili E, Valldeperas FX, Argles T (2016) Recognition of massive Upper Cretaceous carbonate bodies as olistoliths using rudist bivalves as internal bedding indicators (Campanian Merfeg Formation, Central Tunisia). Cretac Res 66: 177-193. https://doi.org/10.1016/j.cretres.2016.06.003

Norton D, Knapp R (1977) Transport phenomena in hydrothermal system: the nature of porosity. Am J Sci 277:913-917

Philip J (1985) Les formations à rudistes du Crétacé en Tunisie. Une revue. Premier Congrès National des Sciences de la Terre, Tunis 1: 235240.

Philip J (2003) Peri-Tethyan neritic carbonate areas: distribution through time and driving factors. Palaeogeogr Palaeoclimatol Palaeoecol 196:19-37. https://doi.org/10.1016/S0031-0182(03)00311-0

Saïdi F, Ben Ismail MH, M’Rabet A (1997) Les récifs Coniaciens à rudistes de Tunisie Centro-Occidentale: sédimentologie, cadre paléogéographique et interprétation séquentielle. J Afr Earth Sci 24(4):531-548. https://doi.org/10.1016/S0899-5362(97)00079-1

Salmouna-Jomaa (2017) Lithostratigraphy and sedimentology of the Turonian-Coniacian Bireno-Douleb carbonates in Gafsa region: correlation with the Gulf of Gabes. Thesis Doc Université Tunis, $253 \mathrm{p}$

Salmouna-Jomaa D, Chaabani F, Dhahri F, Mzoughi M, Salmouna A, Bessaies-Zijlstra H (2014) Lithostratigraphic analysis of the Turonian-Coniacian Bireno and Douleb carbonate Members in Jebels Berda and Chemsi, Gafsa basin, central-southern Atlas of Tunisia. J Afr Earth Sci 100:733-754. https://doi.org/10.1016/j. jafrearsci.2014.07.025

Scheidegger AE (1974) The physics of flow through porous media. University of Toronto Press, $353 \mathrm{p}$

Scott R.W (2003) High resolution North African Cretaceous stratigraphy: status. In: North African Cretaceous Carbonate Platform systems. Kluwer Academic, Amsterdam, pp. 1-17

Skelton PW (2003) In: Skelton PW (ed) The Cretaceous world. The Open University. Cambridge University Press. 360 p

Skelton PW, Gili E (1991) Palaeoecological classification of rudist morphotypes. In: First International Conference on Rudists. Serbian Geological Society, Belgrade, pp. 71-86

Touati MA, Rodgers MR (1998) Tectono-stratigraphic history of the southern gulf of Gabes and the hydrocarbon habitats. In. Proceeding of the 6th Tunisian petroleum exploration and production conference. Entreprise Tunisienne d'Activités Pétrolières (ETAP). EPC, pp. 343-369 
Touir J, Soussi M, Troudi H (2009) Polyphased dolomitization of a shoalrimmed carbonate platform: example from the middle Turonian Bireno dolomites of central Tunisia. Cretac Res 30:785-804. https://doi.org/10.1016/j.cretres.2009.01.004

Troudi H, Negra MH, M’Rabet A (1999) Predictive evaluation of LowerMiddle Turonian carbonate reservoir in Central Tunisia through integration of depositional environment and diagenesis. Ann Mines Géol 40:81-98

Troudi H, Saidi M, Achèche MH, Abassi K (2002) Mid-Cretaceous Platform Carbonate in Tunisia: attributes and evidences from producing fields. Entreprise Tunisienne d'Activités Pétrolières (ETAP). EPC, pp. 329-350

Zagrarni MF (1999) Sédimentologie, stratigraphie séquentielle et diagenèse des faciès du Crétacé supérieur du Jebel Biréno. Paléogéographies des plates-formes carbonatées du Cénomanien supérieur-Coniacien en Tunisie Centrale. Thèse. Doct. Université. Tunis, $358 \mathrm{p}$

Zagrarni MF, Negra MH, Melki S (2003) Turonian rudist-coral limestones in Jebel Biréno, Central Tunisia. In: Gili E, Negra MH, Skelton P (eds) North African Cretaceous Carbonate Platform systems. Kluwer Academic, Amsterdam, pp 111-128

Zagrarni MF, Hennebert M, Negra MH (2007) Mise en évidence du gradient de plate-forme "proximal-distal" par analyse factorielle des correspondances: exemples du Turonien inférieur à moyen au Jebel Biréno (Tunisie centrale). Cret Res 339: 317-328

Zagrarni MF, Negra MH, Melki S (2008) The Cenomanian-Turonian Bahloul Formation in central-north Tunisia. Biosedimentary events and sequence stratigraphy. Sediment Geol 204:18-35

Zinszner B, Pellerin FM (2007) A geoscientist's guide to petrophysics. Publication de l'Institut Français du Pétrole, $384 \mathrm{p}$

Zouari H, Turki MM, Deteil J, Stephan JP (1999) Tectonique transtensive de la paléomarge tunisienne au cours de l'Aptien-Campanien. Bull Soc Géol Fr 3:295-301 


\section{TUNISIAN STRATIGRAPHIC CHART}

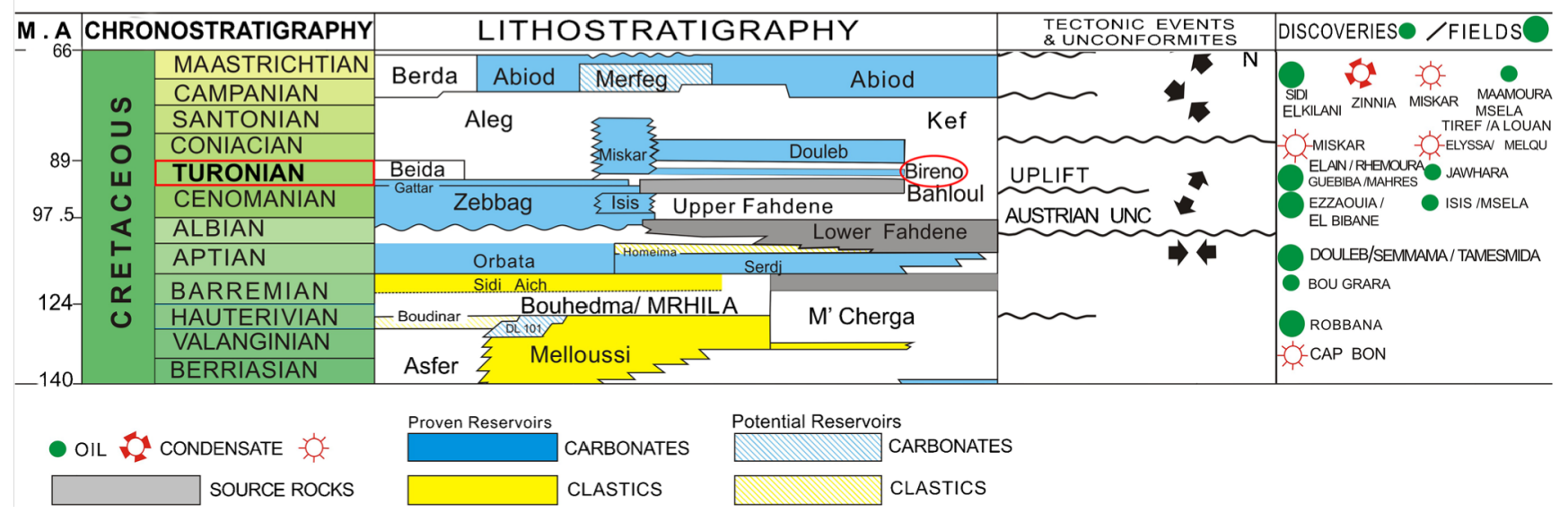

Fig. 1 Excerpt Tunisian stratigraphic chart (ETAP) 


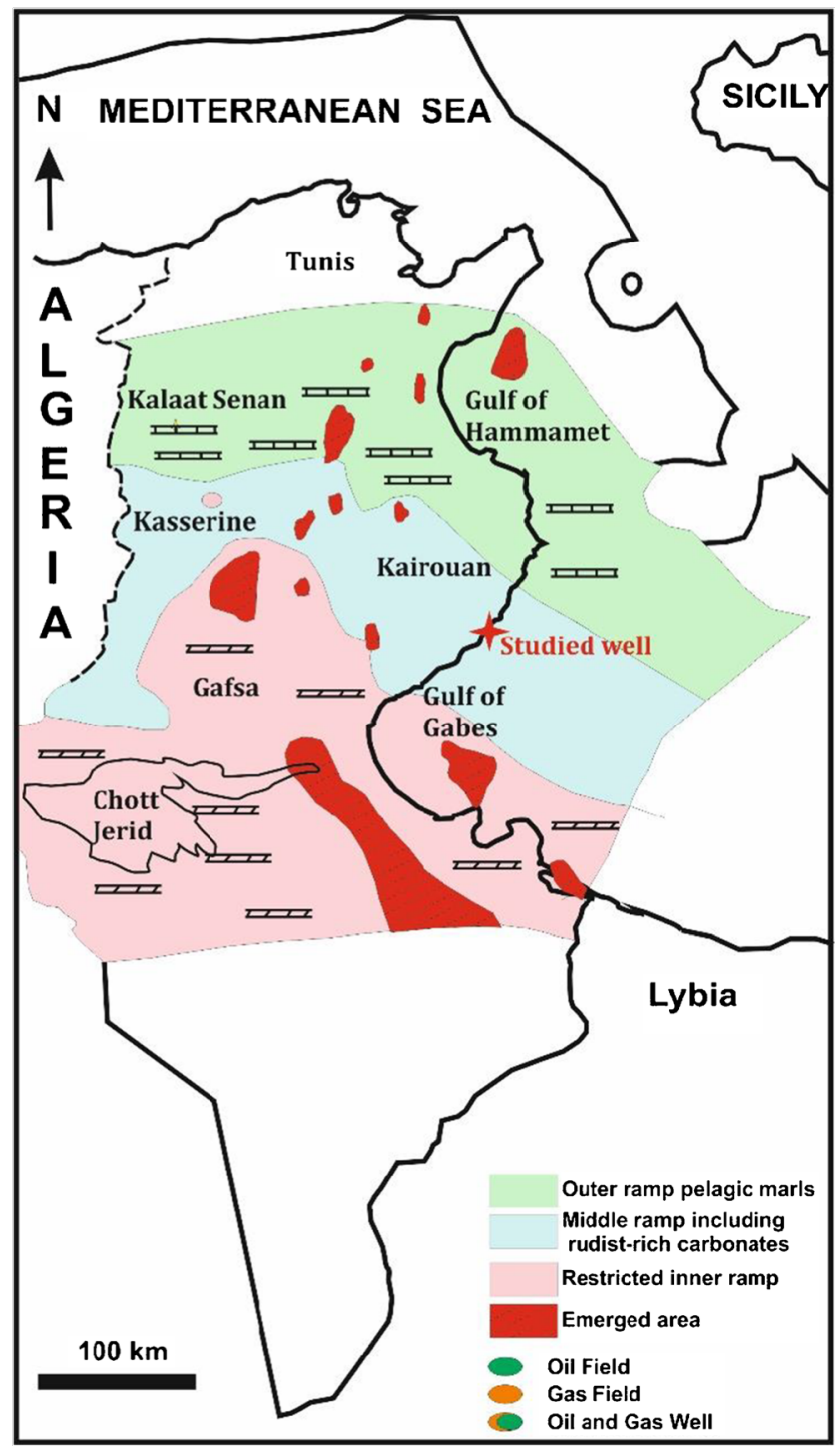

Fig. 2 Location of the studied well on the Early-Middle Turonian paleogeographic map (Marie et al. 1984; Troudi et al. 2002) 


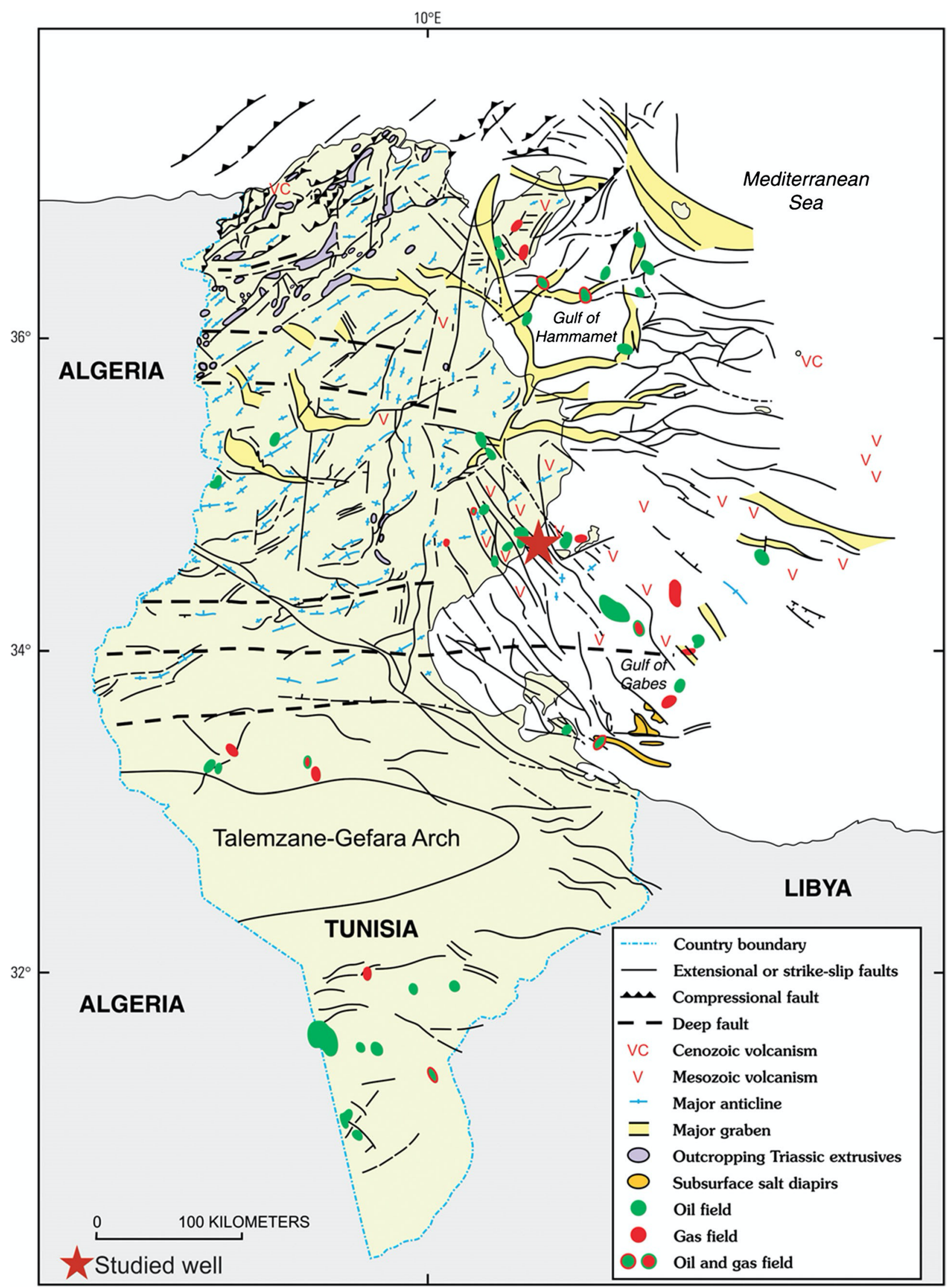

Fig. 3 Location of the studied well on the structural map of Tunisia (Klet 2001) 

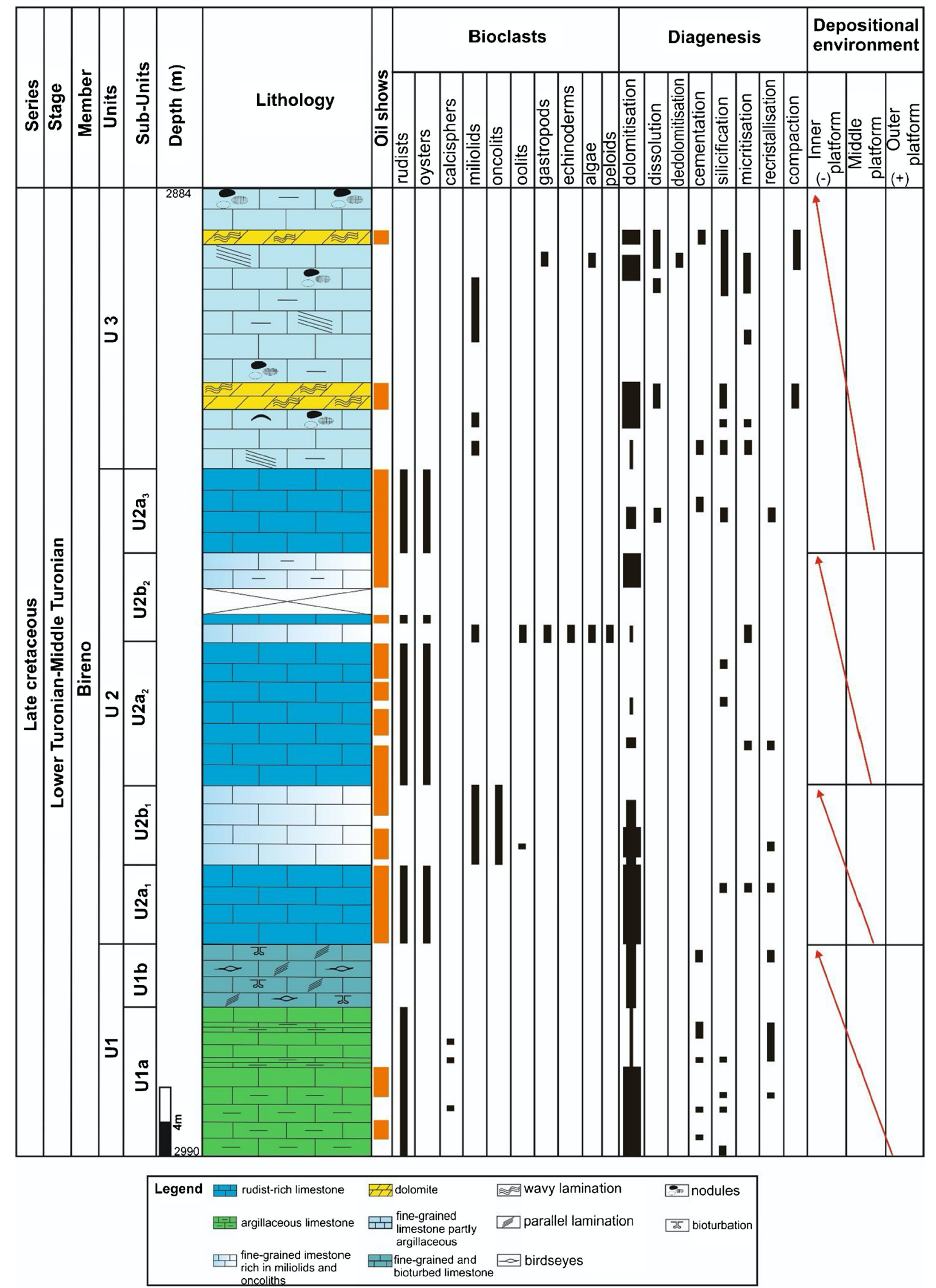

Fig. 4 Detailed log of the Bireno Member in the studied well 


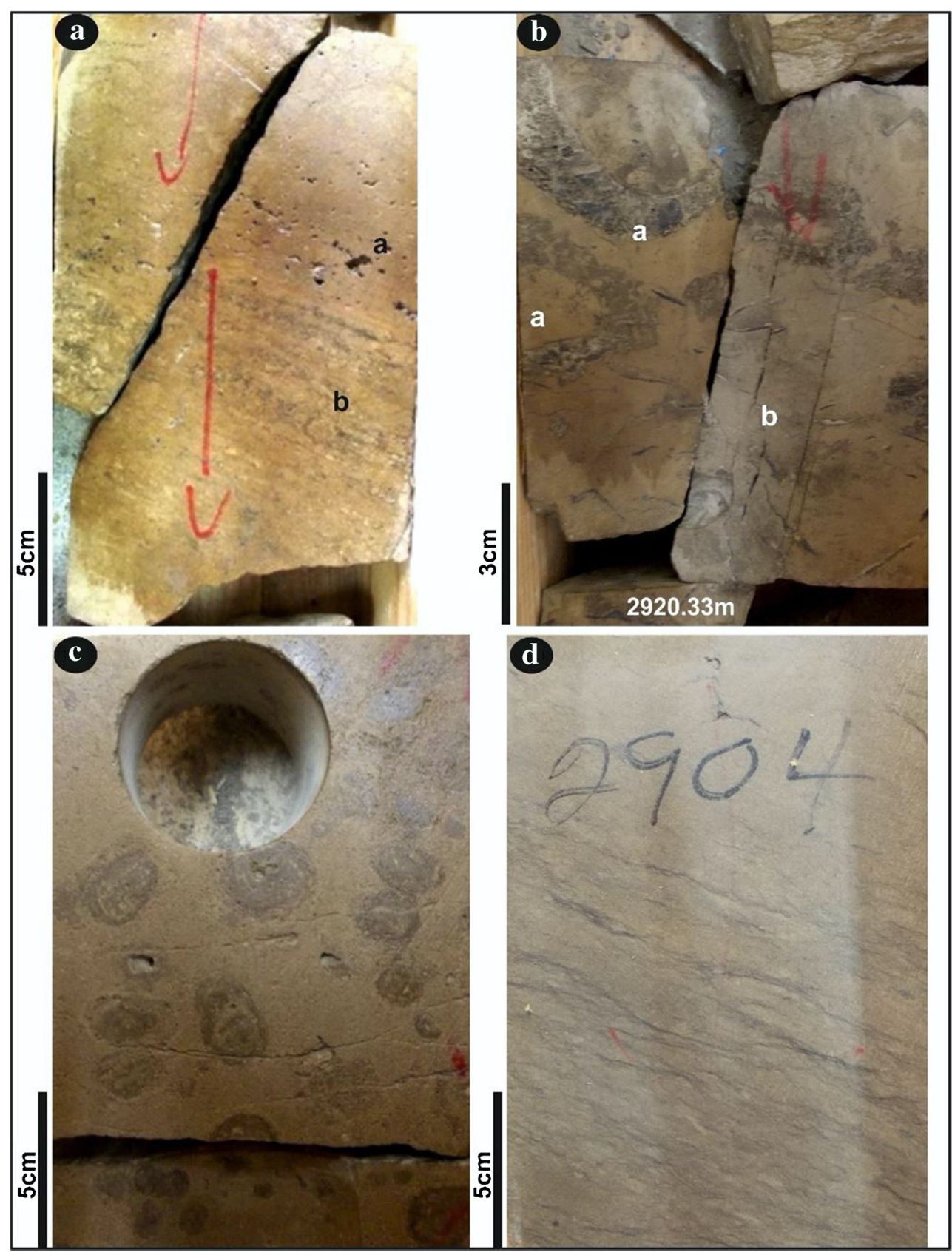

Fig. 5 The main macrofacies of the Bireno Member. a Fine limestone showing birdseyes (a) and parallel lamination (b). b Oil-impregnated

Brown, fine-grained limestone, oil-impregnated and rich in oncoliths limestone rich in rudists (a) showing sub-vertical fractures (b). c 

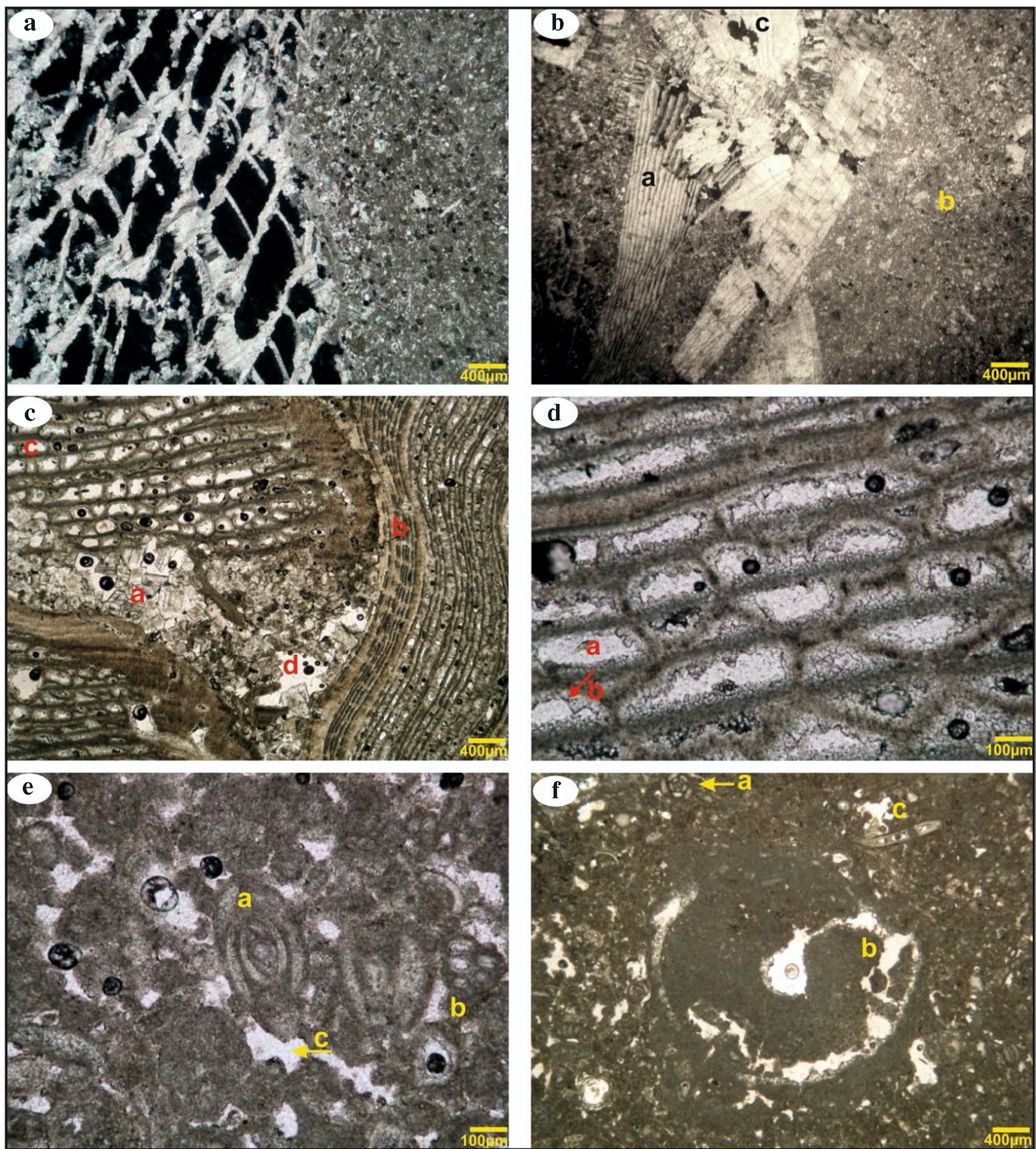

Fig. 6 The main bioclastic and porous facies of the Bireno Member. a Radiolitidae-type rudist showing an important intragranular porosity. b Rudist-rich packstone-type Hippuritidae (a), dolomitised (b) and showing an intragranular porosity (c). c Dolomitised (a) packstonegrainstone rich in rudist-type Radiolitidae (b) showing an important intragranular (c) and intergranular (d) porosity. d Radiolitidae-type rudist showing an important intragranular porosity (a), partly filled with a calcitic cement $(b, c)$. e Fine-grained packstone rich in miliolids (a), benthic foraminifera (Textulariina, b) and showing a matrix porosity (c). $f$ Micritic microfacies rich in miliolids (a), gastropods (b) and showing an intragranular and matrix porosity (c) 


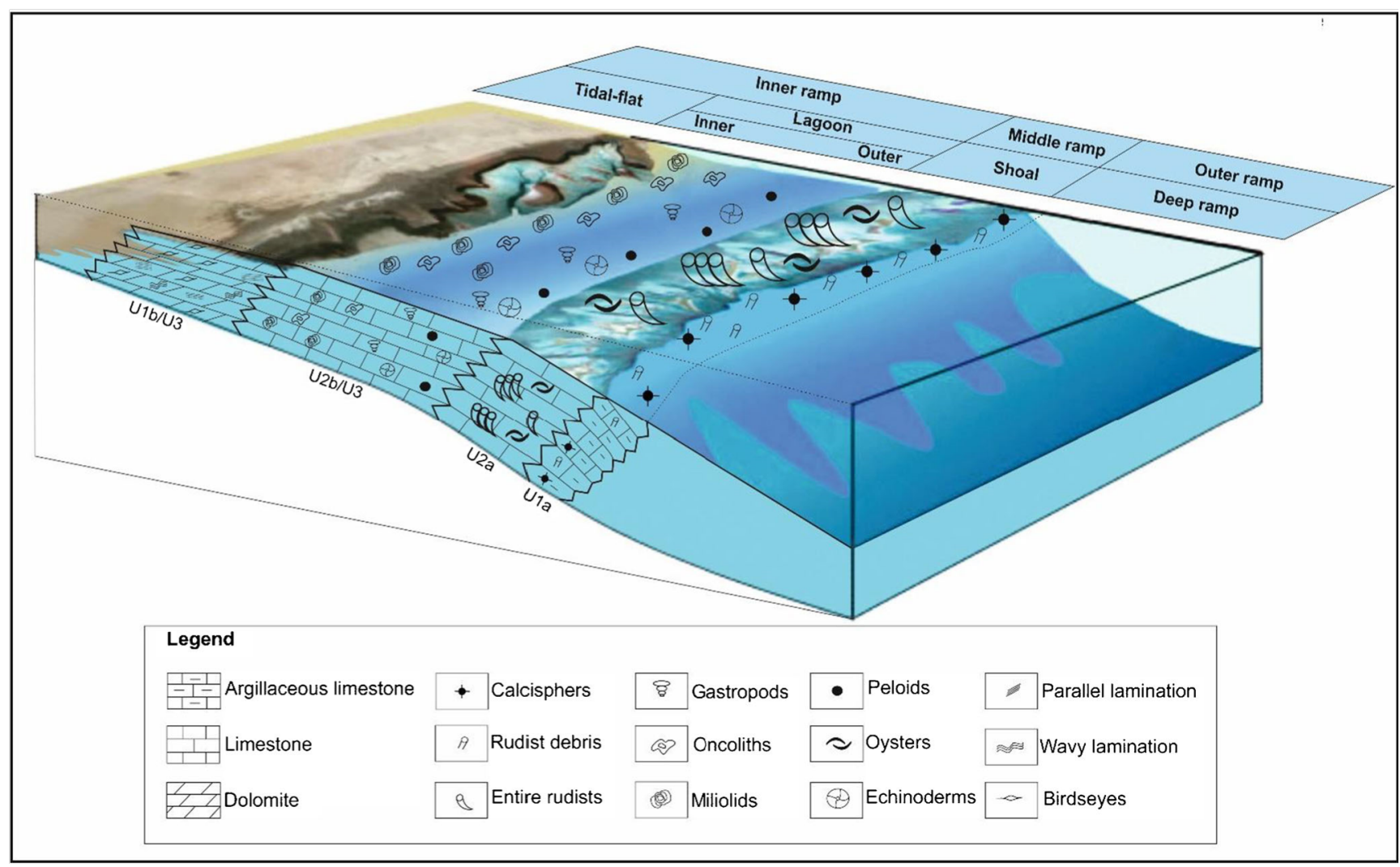

Fig. 7 Bloc diagram of inferred Bireno facies distribution in the studied well 

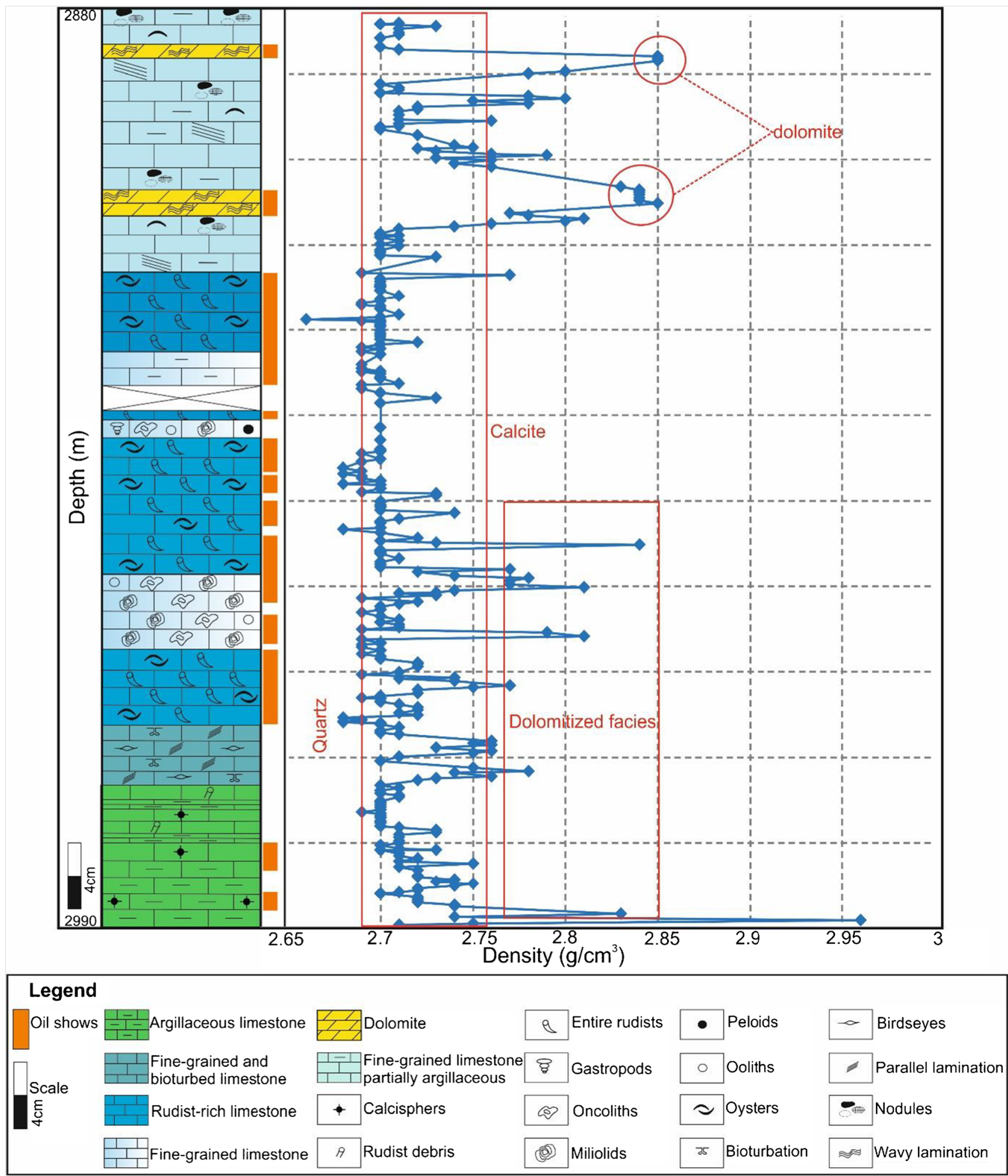

Fig. 8 Density of Bireno carbonates facies versus depth 


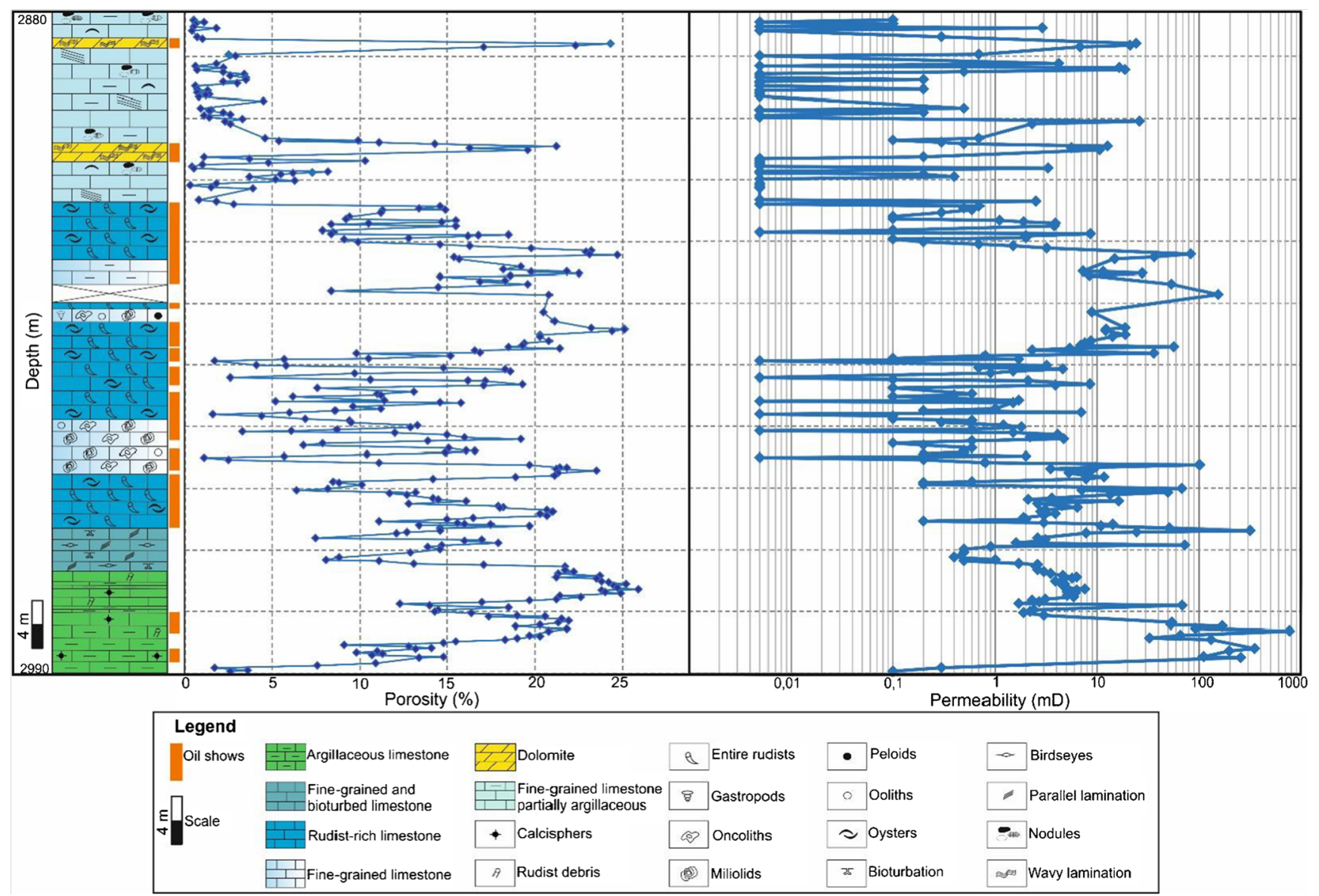

Fig. 9 Vertical evolution of helium porosity and nitrogen permeability 
Fig. 10 Permeability versus porosity

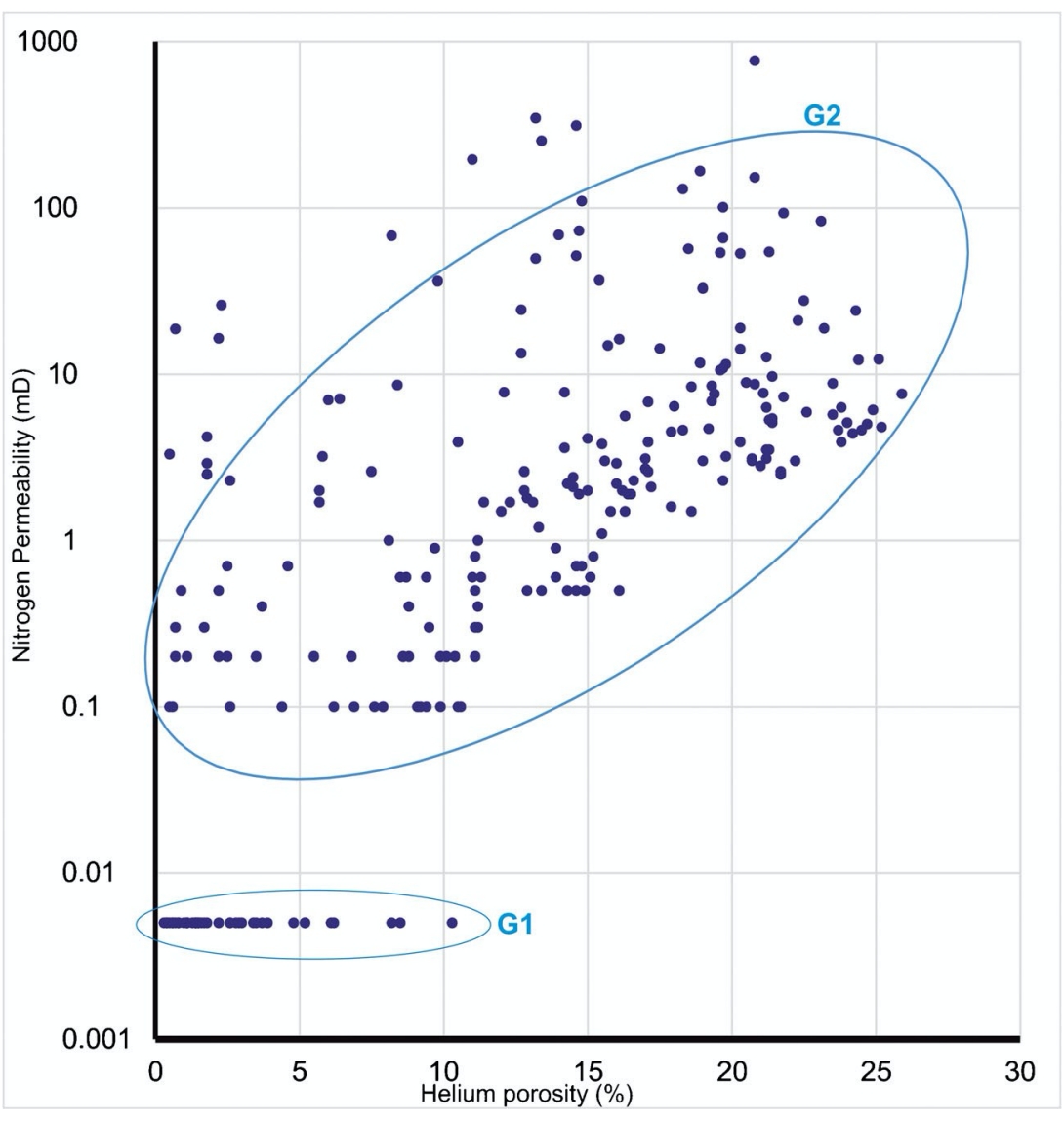




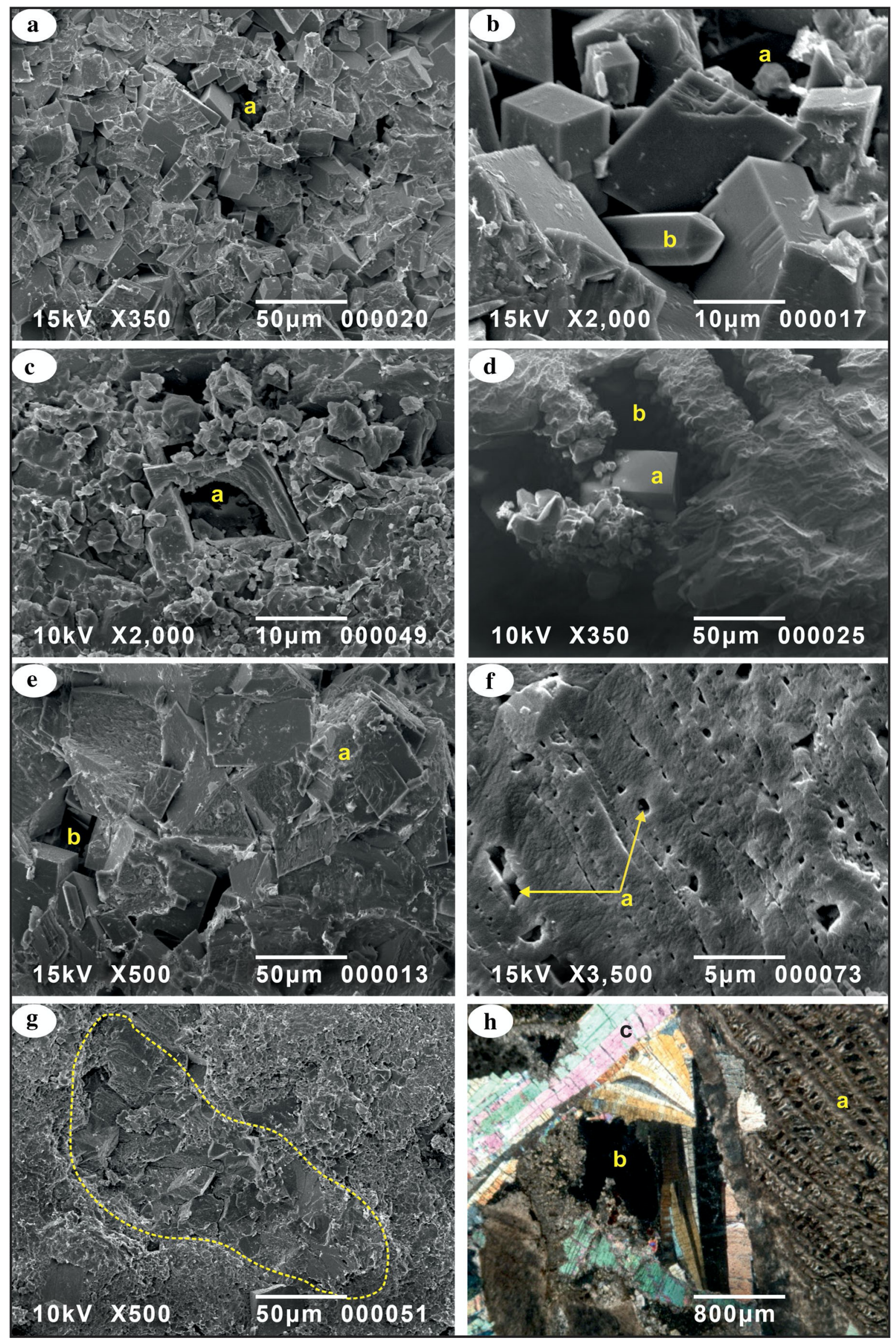


Fig. 11 The different types of porosity and the main diagenetic process characterising the Bireno reservoir. a Creation of intercrystalline porosity between rhombohedral dolomite crystals (a). b Intercrystalline porosity (a) and silicification (b): the pore is filled by hexagonal quartz crystal (b). c Dedolomitisation: SEM photography showing the dissolution of rhombohedral dolomite favouring the creation of secondary intracrystalline porosity type (a). d Cementation of Radiolitidae cells (b) by a rhombohedral dolomite crystal (a). e The compaction that affects dolomites (a) and decreases intercrystalline porosity (b). f SEM photography showing an intraRadiolitidae porosity (a). g Microfracture filled and cemented by dolomites. h Intergranular porosity (a) between Radiolitids (b) cemented by anhydrite (c) 